\title{
A STUDY OF THE QUALITY CLASSROOM MANAGEMENT IN THE SECONDARY SCHOOLS OF KARACHI
}

\author{
Farooq Ahmed \\ Research Scholar, Department of Education, \\ University of Karachi. \\ Karachi, Pakistan \\ Email: farooqa70@yahoo.com
}

\begin{abstract}
The present study aimed at finding out the factors affecting the classroom management at the secondary level. Moreover, this study examined the existing academic and administrative state of schools, how they are supervised, and how they can be made effective to provide quality teaching. The population of the study comprised of the public secondary schools of Karachi. Survey method was used to conduct research. The sample consisted of 400 teachers who were randomly selected from the four towns of Karachi. Twenty two schools were selected through systematic random sampling. The questionnaire was used for collecting data which consisted of 40 items with five-point Likert Scale. The collected data were tabulated, calculated, analyzed, and interpreted in the light of objectives of the study, and the research hypotheses. Moreover, inferential statistics was used for testing of hypotheses i.e. $\chi^{2}$-test.

The following were the conclusions driven from the findings. Teachers believed that they needed support for quality classroom management, head teachers considered subject command that was very important for teaching, teachers monitor students for their adjustment with school environment, head teachers believed in continuous professional development and they believed that such opportunities were very essential for all teachers, school did not provide enough furniture to the students, school had presubscribed rules for students' attendance, school had administrative staff in order to maintain students' record, teachers believed in organizing co-curricular activities as per developed curriculum, teachers did not pay any attention to enhancing teaching methodology and the teaching materials were considered the most important in teaching and learning process, teachers believed that the seasoned senior teachers should have re-checked the marked answer sheets.
\end{abstract}




\section{KEYWORDS}

Quality teaching, Secondary school, Administration, Curriculum

\section{INTRODUCTION}

The term "quality" is very difficult to be defined precisely. The use of this term 'quality' in the educational schools has been increasing all over the world. With the passage of time, the significance of the documentation has increased alarmingly. The audits, assessments are the part and parcel of it. According to Singh, (2006) "Quality may be about excellence, inspection, and conformance to requirements, fitness for purpose, improving customer/client satisfaction, or empowering the customer / client". This concept is used in an absolute and relative way. Using the former one, things which show quality are of the highest possible standard and cannot be surpassed. On the other hand, the relative concept views quality as a characteristic of a service or product, however as something is attributed to it (Sallies, 1996).

The school, chiefly, the high school is a large structure made up of different customer-oriented enterprises, all contending for the student's business. Student engrossed in particular occupational opportunities frequent the specialty shops which are vocation-oriented. Other students are drifting around just casually shopping and socializing. And teachers are the sales employees, trying to get the student customers to buy their products (Elliot, 2005).

The search of the components of classroom teaching apparently leads to the classroom conduct. So, the healthy teacher-student classroom environment of climate has to play a significant role in teaching learning process. It is the atmosphere or mood in which communications between teachers and students take place. So, teaching is not simply a matter of talking (teacher) and listening (student). An important factor in classroom management is producing affable atmosphere. It is deeply concerned to achieve good standards of teaching (Peterson, 2006). Hence, administration or organization of students in classroom is a scaffold for securing and monitoring the collaboration of students in classroom activities. Management and control are an all-around matter which concerns all characteristics of life, school and all features of a student's personality and a teacher's dexterity. Such as, preparation, planning and suitability of 
material are of great importance. Teach methods, teacher-pupil relationship and so on.

Energetic teaching is unworkable without a self-motivated teacher. As a result, an efficient teacher is popular for his or her effective and qualitative teaching. Currently, the education is considered to be child-centered. Therefore, the teaching learning procedure should be aimed at all-round growth of child. The task of teacher in classroom is called 'teaching', which is complex. It is an art. Teaching is more art than science and technology. Like an artist, the teachers' main function is creative decision making about how to act, what to and how to perform in order to achieve. The result he or she desires (Crombie, 1997).

Efforts to improve quality of classroom and teaching-learning process are not new. In recent years, it has received increasing attention. External pressures, from family, society and technological changes have played an important part about the performance of schools. The significance of a qualified teacher in the instructive process cannot be ignored. Consequently, the quality of education is openly connected to the quality of training in the classroom. Teacher is considered the most fundamental aspect in putting into practice all educational transformation at the grass root level. As a nation builder of tomorrow, his or her presentation is the most essential input in the field of education. Whatever polices are given, in the concluding investigation they have to be inferred and put into practice by the teachers though the teaching-learning course of action. So, the elementary role of teachers shall not be only through classroom instruction but numerous other ways to build the character of their pupils. They have also to participate in the management of a variety of services activities, which educational institutions undertake to implement their programs (Pollard, 1993).

\section{OBJECTIVES}

1. To study the features of classroom management related to quality teaching.

2. To investigate the process of retraining of teachers.

3. To examine the academic and professional qualifications of teachers

\section{HYPOTHESES}

1. There will be no significant trend of overall opinion among the teachers about the professional development.

2. There will be no significant trend of overall opinion among the teachers about 
the teaching criteria.

3. There will be no significant trend of overall opinion among the teachers about the students' disciplinary rules.

\section{METHODOLOGY}

The research was based on descriptive study in which survey method was used. The public secondary schools of Karachi were randomly selected in order to collect data. In this study, the population consisted all of the in-service head teachers and teachers placed in the secondary schools of Karachi. The Systematic random sampling had been used for the study. 400 teachers had been selected for a sample size of the study in hand. Through systematic sampling the towns of Gulshan-e-Iqbal, Malir, Gulberg and Liaquatabad were selected. A questionnaire of 40 items for teachers of secondary schools was prepared in consultation of advisor. To supplement the data obtained through questionnaire, interviews were carried out with selected respondents.

TESTING THE HYPOTHESES

Table No. 1: Computation of $\chi^{2}$ for testing the hypothesis No.1

\begin{tabular}{|c|c|c|c|c|c|c|}
\hline S.N. & $\begin{array}{c}\text { Responses } \\
\text { of } Q . \\
\text { No.1,2,3 }\end{array}$ & $f_{o}$ & $f_{e}$ & $f_{o}-f_{e}$ & $\begin{array}{l}\left(\boldsymbol{f}_{o}\right. \\
\left.-\boldsymbol{f}_{e}\right)^{2}\end{array}$ & $\frac{\left(f_{o}-f_{e}\right)^{2}}{f e}$ \\
\hline 1 & $\begin{array}{l}\text { Strongly } \\
\text { Agree }\end{array}$ & 627 & 240 & 387 & 149769 & 624.04 \\
\hline 2 & Agree & 339 & 240 & 99 & 9801 & 40.84 \\
\hline 3 & Undecided & 61 & 240 & -179 & 32041 & 133.50 \\
\hline 4 & Disagree & 147 & 240 & --39 & 1521 & 6.35 \\
\hline \multirow[t]{2}{*}{5} & $\begin{array}{l}\text { Strongly } \\
\text { Disagree }\end{array}$ & 26 & 240 & --214 & 45796 & 190.80 \\
\hline & Total & 1200 & 1200 & & & $\chi^{2}=995.53$ \\
\hline
\end{tabular}

\section{Conclusion}

Referring to table of $\chi^{2}$ we find that tabulated $\chi^{2}=9.49$ with $\mathrm{df}=4$ at $\alpha=0.05$ is smaller than the computed $\chi^{2}=995.53$. Hence, the $\mathrm{H}_{0}$ is rejected and it is concluded that there is a significant trend of overall opinions among the teachers about the professional development.

Table No. 2: Computation of $\chi^{2}$ for testing the hypothesis No.2

\begin{tabular}{ccccccc}
\hline S.N. $\begin{array}{c}\text { Responses } \\
\text { of Q.No. } \\
4,5,6,7\end{array}$ & $f_{o}$ & $f_{e}$ & $f_{o}-f_{e}$ & $\begin{array}{l}\left(f_{o}\right. \\
\left.f_{e}\right)^{2}\end{array}$ & $\frac{\left(f_{o}-f_{e}\right)^{2}}{f e}$ \\
\hline & -43
\end{tabular}


Pakistan Journal of Educational Research, Vol 1, Issue 2 (2018)

\begin{tabular}{|c|c|c|c|c|c|c|}
\hline 1 & $\begin{array}{c}\text { Strongly } \\
\text { Agree }\end{array}$ & 740 & 320 & 420 & 176400 & 551.25 \\
\hline 2 & Agree & 644 & 320 & 324 & 104976 & 328.05 \\
\hline 3 & Undecided & 58 & 320 & -262 & 68644 & 214.51 \\
\hline 4 & Disagree & 112 & 320 & --208 & 43254 & 135.20 \\
\hline \multirow[t]{2}{*}{5} & $\begin{array}{l}\text { Strongly } \\
\text { Disagree }\end{array}$ & 46 & 320 & --274 & 75076 & 234.61 \\
\hline & Total & 1600 & 1600 & & & $\chi^{2}=1463.62$ \\
\hline
\end{tabular}

\section{Conclusion}

Referring to table of $\chi^{2}$ we find that tabulated $\chi^{2}=9.49$ with $\mathrm{df}=4$ at $\alpha=0.05$ is smaller than the computed $\chi^{2}=1463.62$. Hence, the $\mathrm{H}_{0}$ is rejected and it is concluded that there is a significant trend of overall opinions among the teachers about the teaching criteria.

Table No. 3: Computation of $\chi^{2}$ for testing the hypothesis No.3

\begin{tabular}{|c|c|c|c|c|c|c|}
\hline S.N. & $\begin{array}{c}\text { Responses } \\
\text { of Q. No. } \\
\text { 14,15, 16, } 17\end{array}$ & $f_{o}$ & $\boldsymbol{f}_{e}$ & $f_{o}-f_{e}$ & $\begin{array}{l}\left(f_{o}\right. \\
\left.-f_{e}\right)^{2}\end{array}$ & $\frac{\left(f_{o}-f_{e}\right)^{2}}{f e}$ \\
\hline 1 & $\begin{array}{c}\text { Strongly } \\
\text { Agree }\end{array}$ & 613 & 320 & 293 & 85849 & 268.28 \\
\hline 2 & Agree & 715 & 320 & 395 & 156025 & 487.58 \\
\hline 3 & Undecided & 48 & 320 & -272 & 73984 & 231.20 \\
\hline 4 & Disagree & 143 & 320 & --177 & 31329 & 97.90 \\
\hline \multirow[t]{2}{*}{5} & $\begin{array}{l}\text { Strongly } \\
\text { Disagree }\end{array}$ & 81 & 320 & --239 & 57121 & 178.50 \\
\hline & Total & 1600 & 400 & & & $\chi^{2}=1263.46$ \\
\hline
\end{tabular}

\section{Conclusion}

Referring to table of $\chi^{2}$ we find that tabulated $\chi^{2}=9.49$ with $\mathrm{df}=4$ at $\alpha=0.05$ is smaller than the computed $\chi^{2}=1263.46$. Hence, the $\mathrm{H}_{0}$ is rejected and it is concluded that there is a significant trend of overall opinions among the teachers about the students' evaluation.

Table No. 4: Computation of $\chi^{2}$ for testing the hypothesis No.4

\begin{tabular}{cccccc}
\hline S.N. $\begin{array}{c}\text { Responses } \\
\text { of Q. No. } \\
19,20,21,23\end{array}$ & $f_{o}$ & $f_{e}$ & $f_{o}-f_{e}$ & $\left(f_{o}\right.$ & $\frac{\left(f_{o}-f_{e}\right)^{2}}{f e}$ \\
\hline
\end{tabular}


Pakistan Journal of Educational Research, Vol 1, Issue 2 (2018)

\begin{tabular}{|c|c|c|c|c|c|c|}
\hline 1 & $\begin{array}{c}\text { Strongly } \\
\text { Agree }\end{array}$ & 807 & 320 & 487 & 237169 & 741.15 \\
\hline 2 & Agree & 703 & 320 & 383 & 146689 & 458.40 \\
\hline 3 & Undecided & 32 & 320 & -288 & 82944 & 250.20 \\
\hline 4 & Disagree & 40 & 320 & --280 & 78400 & 245 \\
\hline \multirow[t]{2}{*}{5} & $\begin{array}{l}\text { Strongly } \\
\text { Disagree }\end{array}$ & 18 & 320 & --302 & 91204 & 285.01 \\
\hline & Total & 1600 & 400 & & & $\chi^{2}=1979.76$ \\
\hline
\end{tabular}

\section{Conclusion}

Referring to table of $\chi^{2}$ we find that tabulated $\chi^{2}=9.49$ with $\mathrm{df}=4$ at $\alpha=0.05$ is smaller than the computed $\chi^{2}=1979.76$. Hence, the $\mathrm{H}_{0}$ is rejected and it is concluded that there is a significant trend of overall opinions among the teachers about the students 'disciplinary rules.

Table No. 5: Computation of $\chi^{2}$ for testing the hypothesis No.5

\begin{tabular}{|c|c|c|c|c|c|c|}
\hline S.N. & $\begin{array}{c}\text { Responses of } \\
\text { Q. No. } \\
\text { 35,36, 37, } 39\end{array}$ & $f_{o}$ & $f_{e}$ & $\boldsymbol{f}_{o}-\boldsymbol{f}_{\boldsymbol{e}}$ & $\begin{array}{l}\left(f_{o}\right. \\
\left.-f_{e}\right)^{2}\end{array}$ & $\frac{\left(f_{o}-f_{e}\right)^{2}}{f e}$ \\
\hline 1 & $\begin{array}{c}\text { Strongly } \\
\text { Agree }\end{array}$ & 492 & 320 & 172 & 29584 & 92.45 \\
\hline 2 & Agree & 979 & 320 & 659 & 434281 & 1357.13 \\
\hline 3 & Undecided & 33 & 320 & -287 & 82369 & 257.41 \\
\hline 4 & Disagree & 67 & 320 & --253 & 64009 & 200.03 \\
\hline \multirow[t]{2}{*}{5} & $\begin{array}{l}\text { Strongly } \\
\text { Disagree }\end{array}$ & 29 & 320 & --291 & 84681 & 264.62 \\
\hline & Total & 1600 & 400 & & & $\chi^{2}=2171.63$ \\
\hline
\end{tabular}

\section{Conclusion}

Referring to table of $\chi^{2}$ we find that tabulated $\chi^{2}=9.49$ with $\mathrm{df}=4$ at $\alpha=0.05$ is smaller than the computed $\chi^{2}=2171.63$. Hence, the $\mathrm{H}_{0}$ is rejected and it is concluded that there is a significant trend of overall opinions among the teachers about the physical facilities.

\section{DISCUSSION}

Education is considered to be matter of life and death for a nation because without education, the country cannot make any head way in terms of economic growth, and better living standard of the masses. The sole aim of education to reveal the 
systematic and scientific results towards fulfilling the needs of masses and society. Studies need to be carried out in order to expand all related sub-systems in educational structure regarding the needs and expectation of the people.

Teachers' training is very necessary in educational in order to address the real causes in the first place. The indispensable purpose of teachers' training is to make sure efficient administration, growth and supervision of educational system by equipping teachers with certain competencies. The notion of teachers' competencies is usually discussed in very narrow scope like teachers' planning execution, evaluation of the set of courses, principles for the syllabus or the school. These are related to teachers' duties in the school in this respect. Teachers' effectiveness needs to be discussed in many proportions such as curriculum competencies, field competencies and research competencies, constant learning competencies, socialcultural competencies, emotional competencies, communication competencies, information and communication technologies competencies and environmental competencies for developing teachers. The development in different fields and the transitions in human life need be discussed so that the troubles could be addressed. The ecological competencies were not addressed over a span of few decades. However, the problems experienced by people regarding environmental issues have been linked with education and teaching. Therefore, environment issues have been under discussions for a long time. The daily life and all the developments related to human requirements affect teaching occupation and the teacher competencies. The teacher's specialized competencies must include the program of study competencies. The set of courses competencies are central part for teachers' professional developments. Teachers' curriculum development competencies are indistinguishable because the teachers have been facing innumerable problems with reference to the curriculum development and execution of curriculum in their fields.

Understanding the philosophy of program of study, theory and development models of curriculum, curriculum development studies, learning and teaching approaches have been neglected aspects regarding teachers' curriculum competencies. Curriculum competencies of teachers are associated to micro and macro level curriculum design, development and execution. Teachers' curriculum competencies are indispensable for developing association between teachers and the curriculum development. Curriculum development teams along with the teachers should have to play their pivotal role in the curriculum development course of action. The approach of teacher-oriented program of study will become 
imperative in the forthcoming time. However, school-based program of study should be encouraged by teachers' research and execution.

At the same time, it will give confidence to teachers to become more active participants in the curriculum development procedure. In spite of this, set of courses writers, namely curriculum design and development team do not successfully pass on their thoughts to teachers. Therefore, curriculum studies should be expected by curriculum theorists and teachers jointly. It is understood that curriculum studies strengthen teachers' work. As a result, teacher competencies in relation to curriculum are of great significance for teachers to continue their occupation. The competencies of teacher cover theory and practice of program of study. At the same time, defining teachers' competencies will contribute to the enhancement in the quality of educational system by positively influencing teacher training and curriculum improvement.

The transitions in science and educational system have an effect on teacher's competencies. There is strong association between science and system of society that influence educational system and teachers' competencies. Educational system counts on scientific outcome of educational sciences, psychology, financial system, technology and sociology. The change and transformation in the others systems or science harm teachers' professional competencies if not teacher's competencies are enhanced. Teachers should pursue changes in order to get better their professional presentation. The improvement of teacher's competencies depends on the changes in society and other sciences and these are not connected with only the personal growth but also professional. Nowadays, we give a vent to our emotions regarding internationalization of program of study.

The perception of internationalizing program of study is a kind of transformation in study whereas the teachers make sure these changes to be implemented. It is the sole responsibility of teachers to enhance their abilities and competencies whatever they have been using in the past. The teachers' abilities should be discussed and modernized by taking the international developments into consideration. The teachers' efficiency is very imperative in both implementing the recent and updated set of courses successfully and schooling people for future. Teachers should fulfill their responsibilities in the first place.

Teacher's ability is considered to be the subject of betterment in future research. For that reason, teacher education development specialist and a teacher trainer 
should assist them during pre-service and in-service. It is believed that teachers' abilities should replicate developing situation for sustainability. Most of the improvements of teacher's competencies do not shape a regular process but some developments can take place by chance with the passage of time. The capabilities of teachers should be brought into consideration over and over again in parallel with the changes and transformations through scientific studies. The most important role of teachers is considered to implement these changes into educational system effectively.

The future of students depends on toil and laborious work of the teachers. Without efficient teachers, no headway can be made in the country. Conclusively, ineffective administration, non-flexible curriculum and outdated teaching methods used by teachers are the major reasons of declining educational standards at the secondary level in our country.

\section{RECOMMENDATIONS}

1. The secondary level curriculum should be improved according to the needs of time and wishes of the society.

2. The secondary school teachers must use modern teaching methods according to the age and psychological requirements of students.

3. Opportunities should be provided to the students for participating in different co-curricular activities.

4. The process of professional development must be ongoing. Individuals should be trained in order to practice a particular profession after finishing their training.

5. Teaching environments should be conducive and congenial. Furthermore, the competencies required for day-to-day teaching can be exercised in a variety of contexts.

6. There should be a command on subject areas. The competencies involved in teaching also relate to the resources i.e. knowledge, skills, attitudes which are associated with each subject area. A teacher should know how to be active in several subject areas.

7. It is era of science and technology, the teacher should learn technology in order to promote technological culture in their schools.

8. The teachers should have knowledge of a variety of the latest teaching methods or techniques, and questioning session in the classes by the students should be encouraged. 


\section{CONCLUSION}

The overall sole purpose was to study the quality teaching in the secondary schools of Karachi. Some conclusions were drawn from the findings. Teachers believed that they needed support of students for quality education. Head teachers considered subject command that was very important for teaching. The teachers monitor students for their adjustment with school environment. Head teachers believed in continuous professional development and they also believed that such opportunities were very essential for all teachers. School did not provide enough furniture to the students. School had presubscribed rules for students' attendance. School had administrative staff in order to maintain students' record. Teachers believed in organizing co-curricular activities as per developed curriculum. Teachers did not pay any attention to enhancing teaching methodology and the teaching materials were considered the most important in teaching and learning process. The Teachers believed that the seasoned senior teachers should have re-checked the marked answer sheets.

\section{REFERENCES}

Abdullah, S.M. (1992) Stray Thoughts on Education in Pakistan: Lahore: Bazm-eIqbal.

Abdur Rashid Arshad. (1995) Gum gashta Manzal ka Suragh: Talim Ka Aik Islahi Mansuba $(U r d u)$. Lahore: Idarah Talimi Tehqiq.

Agarwal, J.C. (2004) Teacher and Education in Developing Society. New Delhi: Vikas Publishing House.

Agarwal, J.C. (2007) Development and Planning of Modern Education. New Delhi: Vikas Publishing House.

Al-Afandi, M.A. and Baloch, N.A. (1980) Curriculum and Teacher Education.

Babbie, E. and Andreson, R. (2011) Introduction to Social Research. Australia: Wadsworth.

Best, W., and Khan, J. (1992) Research in Education. New Delhi: Prentice-hall of India Pvt. Ltd.

Bhaskara, R.D. (2003) School Curriculum and Administration. New Delhi: S.R. Publishing House.

Carbetta, P. (2003) Social Research: Theory, Methods and Techniques. London: Sage. 
Cazden, C. (2000) In Ensuring Learning Takes Place: A focus on literacy. Paper prepared for Human Development Week. Washington: World Bank.

Chisti, S. et al. (2011) "Quality School Education in Pakistan: Challenges, Success and Strategies". International Journal of Academic Research. Karachi.

Delpit, L. (2002) Other People's Children: Cultural Conflict in the Classroom. New York: The New Press.

Desai, V. and Pooter, R. Eds. (2006) doing development research. New Dehli: Vistaar.

Dewey, J. (1938) Experience and Education. New York:Collier Books.

Diana, F.W. (2004) Supporting Teachers Supporting Pupils. New York: Cassell.

Ediger, M. and Rao B. D. (2006) Improving School Administration. New Delhi: Discovery Publishing.

Elliot, Daniel, C. (2005) Teaching on Target: Models, Strategies, and Methods that Work. London: Sage.

Fredrick, D.A. (2007) Teaching. New York: Alpha.

Government of Pakistan. (2006) Education Census 2005. Islamabad Ministry of Education.

Groundwater-Smith, S. et al. (2003) Secondary Schooling in a Changing World. Australia: Thomson.

Guthrie, G. (2010) Basic Research Methods: An Entry to Social Science Research. London: sage.

Henn, M. Weinstein, M. and Foard, M. (2006) A Short Introduction to Social Research. New Delhi: Vistaar.

Hunt, A. (2006) Your Research Project, How to Manage It. London: Rutledge Taylor \& Francis Group.

Iqbal, M. Zafar and Sufian K. (2005) Some Problem Areas of Teacher Education in Pakistan. Pakistan Journal of Education .Islamabad: XXII/1:3-14.

Iqbal, M. Zafar, M Ramzan and Mahmood H. Awan, (2004) A Comparative Study of the Teacher Education System of the United Sates of America and Pakistan. Pakistan Journal of Education. Islamabad: XXI/2: 15-38.

Killen, R. (2005). Effective Teaching Strategies. Australia: Thomson.

Kyriacou, C. (2006) Effective Teaching in Schools: Theory and Practice. U.K: Nelson Thornes Ltd.

Lomax, Pamela. Ed. (1996) Quality Management in Education. London: Routledge.

Oser, F.K. et al. Eds. (1992) Effective and Responsible Teaching: The New Synthesis. San Francisco: Jossey-BQSS.

Pandey, M. (2007) Principles of Curriculum Development .New Delhi: Rajat. 
Picciano, A.G. (2007) Educational Research Primer. New York: Continuum. Pigozzi, M. J. (2000). Issues paper: Strategy Session on Girl's Education. World Pithers, R.T. (1998) Improving Learning Through Effective Training. Australia: Social Science Press.

Porter, L. (2000) Student Behaviour: Theory and Practice for Teachers. Australia: Allen \& Unwin.

Ryan, K. and Cooper, J.M. (2001) Those Who Can Teach. New York: Houghton.

Saad, Ismail. (1986). The Educational Challenges to Islam. In The Changing World of Islam.Ed. by Jameel Jalibi and kazi A. Kadir. Karachi: University of Karachi Press.

Saeed, A. (1998) Organizational Commitment of Teachers in Government, K.M.C. and Private Primary Schools of Karachi. Karachi: PhD Dissertation Hamdard University Karachi .

Safdar, Q. and Khaki, J.A. (2010) Educational Leadership in Pakistan. Karachi: Oxford University Press.

Sallis,E (1996) Total Quality Management in Education. London: Kogan Page Limited.

SIDA. (2000). Teacher Education, Teachers' Conditions and Motivation.

Stockholm: Department for Democracy and Social Development, Education Division.

Sindh Education management information system (SEMIS) (2010) Karachi.

Schools Profile Karachi: SEMIS.

Singh,U.K. and Sudarshan, K.N. (2006) Quality Education. New Delhi: Discovery Publishing. 